\title{
PREGNANCY Following FAILED STERILISATION UNDER THE ACCIDENT COMPENSATION SCHEME
}

\author{
Yasmin Moinfar
}

This paper analyses the approach that is taken in New Zealand in determining coverage for pregnancies following failed sterilisations under the accident compensation scheme. The approach adopted in the recent decision of the Court of Appeal in ACC v D is criticised and an alternative approach for determining whether such claims ought to be within the accident compensation scheme is suggested.

\section{INTRODUCTION}

The prevention of litigation is a fundamental lesson of the Woodhouse Report. ${ }^{1}$ The intention of the Woodhouse Commission was to replace the need for adversarial, fault-based proceedings ${ }^{2}$ and to "supplant the vagaries of actions for damages for negligence at common law" 3 by providing a comprehensive accident compensation scheme. The scheme generally operates successfully and continues to command widespread support, ${ }^{4}$ yet notwithstanding its comprehensive, no-fault nature, there are "peripheral problems around the extent to which some common law actions may still be available". 5

* Submitted as part of the LLB(Hons) programme at Victoria University of Wellington.

1 Grant Duncan "Boundary Disputes in the ACC Scheme and the No-Fault Principle" [2008] NZ Law Review 27 at 27, referring to the New Zealand Royal Commission to Inquire into and Report upon Workers Compensation Compensation for personal injury in New Zealand: Report of the Royal Commission of Inquiry (Wellington, 1967) [Woodhouse Report].

2 Ibid, at 35.

$3 \quad$ Willis v Attorney-General [1989] 3 NZLR 574 (CA) at 576.

4 Stephen Todd (ed) The Law of Torts in New Zealand (5th ed, Brookers, Wellington, 2009) at 22.

5 Geoffrey Palmer "Accident Compensation in New Zealand: Looking Back and Looking Forward" [2008] NZ Law Review 81 at 90. 
In New Zealand, "wrongful birth" cases have been described as common law actions on the margin, and a minefield for both the common law and the accident compensation scheme. ${ }^{6}$ Rosemary Tobin defines a "wrongful birth" action as one brought by the parents of a healthy or defective child who is born as a result of medical negligence, often due to the failure of a sterilisation operation, or where the medical professional did not warn the parents that the procedure may not be entirely effective. ${ }^{7}$ The difficulty with these cases has been in deciding whether they are covered under the accident compensation scheme, as the courts have struggled with identifying pregnancy (whether it is the conception, pregnancy itself, or childbirth) as a personal injury. ${ }^{8}$

The Court of Appeal's 2008 decision in $A C C v D$ determined that there could not be cover under New Zealand's accident compensation scheme for pregnancy following a failed sterilisation of the mother. ${ }^{9}$ In a split decision, Ellen France and Arnold JJ held that pregnancy could not be viewed as a "personal injury" for the purposes of the Injury Prevention, Rehabilitation, and Compensation Act 2001 (now called the Accident Compensation Act 2001 (the 2001 Act)). William Young P dissented, in a short judgment where he stated that he saw the statutory expressions "personal injury", "physical injuries" and "gradual process" as sufficiently broad to encompass unwanted pregnancy which results from medical misadventure.

The effect of the Court of Appeal's decision is to create a class of persons who can not be covered by the accident compensation scheme due to the nature of their "personal injury", despite real consequences arising from a medical misadventure (or since amended, treatment injury). Conversely, a by-product of this decision is to open the door to civil actions against the doctors performing these operations. It is arguably an unsatisfactory position for cover and the availability of the civil damages action to depend on the fortuity of what kind of injury a person suffers. It is also difficult to justify leaving the medical professionals in these types of circumstances exposed to common law claims when the policy of the accident compensation regime is to exclude such claims. Doctors already face internal disciplinary mechanisms in the medical profession which are available despite the accident compensation scheme.

The approach of the courts in relation to unwanted pregnancies following failed sterilisations illustrates how judicial interpretations of the compensation scheme have varied depending on the particular legislation they are faced with. This article criticises the majority judgment in the Court of Appeal in $A C C v D$ for taking an unduly restrictive approach towards cover. It is suggested that an inclusive interpretation of the accident compensation scheme is appropriate for cases on the borderline, such as $A C C v D$. When confronted with such a case, the courts should err on the side of

6 Rosemary Tobin "Common Law Actions on the Margin" [2008] NZ Law Review 37 at 46.

7 Ibid.

8 Ibid.

$9 \quad A C C v D[2008]$ NZCA $576[D]$. 
caution, granting cover. If this is not seen to be an appropriate outcome, Parliament can make legislative changes as it sees fit.

\section{ACC v D}

\section{A Facts}

The case in issue arose after a doctor had performed a sterilisation operation on $\mathrm{D}$, who later became pregnant and gave birth. ${ }^{10}$ The child needed ongoing medical assistance. $\mathrm{D}$ sought accident compensation cover for herself under the 2001 Act on the basis of medical misadventure. ${ }^{11}$ In her claim the injury was described as her pregnancy. ${ }^{12}$ In order for there to be cover, D had to have suffered a "personal injury caused by medical misadventure" under the 2001 Act. ${ }^{13}$ The term "personal injury" as defined, ${ }^{14}$ required D to have suffered "physical injuries". ${ }^{15}$ However, whether or not the pregnancy was caused by medical misadventure or whether medical misadventure occurred did not fall for determination, as the matter would be referred back to a reviewer (under the compensation authority's review process) if it was found that pregnancy could constitute a "personal injury". ${ }^{16}$

The Accident Compensation Corporation (the Corporation) declined cover, in part because it considered that the definition of personal injury was not satisfied. On review, the Corporation's decision was upheld on the basis that pregnancy is a natural physiological function, not a personal injury. Judge Cadenhead on appeal to the District Court disagreed, and allowed her appeal. ${ }^{17}$

\section{B High Court Decision}

In the High Court, before Mallon J, the Corporation argued that pregnancy was not a physical injury and therefore not a "personal injury" as required under the Act. ${ }^{18}$ Her Honour said that as a matter of statutory interpretation, the meaning of the words "physical injuries" had to be considered

$10 A C C v D[2007]$ NZAR $679(\mathrm{HC})$ at [2] [ACC v D].

11 At that time called the Injury Prevention, Rehabilitation, and Compensation Act 2001, s 20(2)(b), now called the Accident Compensation Act 2001 [ACA]. This was before the concept of "medical misadventure" was replaced by "treatment injury" through s 13 of the Injury Prevention, Rehabilitation, and Compensation Amendment Act (No 2) 2005.

$12 D$, above n 9 , at [2].

13 ACA, above n 11.

14 Ibid, s 26.

15 Ibid, s 26(1)(b).

$16 A C C v D$, above n 10, at [3].

17 ACC v D DC Wellington AI360/04, 25 August 2005.

$18 A C C v D$, above n 10 , at [10]. 
in their context and in light of their purpose. ${ }^{19}$ She held that "physical injury" under the Act meant bodily harm or damage, ${ }^{20}$ and interpreted widely, could include "interference with bodily integrity". 21

Her Honour considered that the physical changes to a woman's body during pregnancy were a harm or an invasion of bodily integrity and therefore injuries, ${ }^{22}$ particularly when viewed from the perspective of the woman's body in its pregnant state as compared with its pre-pregnant state. Whilst Mallon J acknowledged that these physical changes are a natural process, and thus ostensibly not covered by the Act, ${ }^{23}$ she said that the Act excluded only certain gradual processes, not all natural processes (such as pregnancy) per se. ${ }^{24}$ Pregnancy could therefore be a "personal injury", and would qualify for cover if arising from medical misadventure.

Further, Mallon J said that the policy of the 2001 Act was to provide comprehensive cover for personal injury in New Zealand as a corollary of giving up the right to sue, ${ }^{25}$ and that cases from Australia and England illustrated that pregnancy is able to be described as an "injury". She saw these factors as strongly supporting an "unniggardly" interpretation of "physical injury". ${ }^{26} \mathrm{Her}$ Honour therefore took a generous, inclusive approach to the accident compensation scheme, granting cover.

\section{Court of Appeal Decision}

In the Court of Appeal, the Corporation argued that since 1992, when the accident compensation legislation separated the concept of personal injury from that of causation, there has been a stand alone requirement for personal injury. It contended that the words "personal injury" connote a need for harm or damage, so the natural process of pregnancy is not included in this phrase. The Corporation further submitted that Mallon $\mathrm{J}$ erred in not correctly assessing the effect of the

19 Ibid, at [12].

20 Ibid, at [66].

21 Ibid, at [68] - [69]. This was the test adopted by Baragwanath $\mathrm{J}$ in Patient A $v$ Health Board X HC Blenheim CIV-2003-406-14, 15 March 2005, and originally seen in Green v Matheson [1989] 3 NZLR 564 (CA) at 572.

22 Ibid, at [76].

23 ACA, above n 11, s 26(2).

$24 A C C v D$, above n 10, at [84].

25 Ibid, at [65].

26 Ibid, at [93]. 
legislative changes from 1992, which suggested a less inclusive approach to accident compensation. $^{27}$

The Court of Appeal majority determined that the High Court had been wrong in law in its conclusion. The majority judgment of the Court of Appeal stands in marked contrast to Mallon J's judgment. Their divergence in opinion relates to a number of matters, including: the natural and ordinary meaning of the terms "personal injury" and "physical injury" in the 2001 Act; the relevance of common law developments to inform the interpretation of the 2001 Act; and the underlying policy behind the accident compensation scheme. William Young P's dissenting judgment, in contrast with the majority, is brief and largely turns on his Honour seeing the relevant statutory expressions as sufficiently expansive to encompass unwanted pregnancy which results from medical misadventure. ${ }^{28}$

In the majority's view, the natural and ordinary use of the terms "personal injury" and "physical injury" in the 2001 Act did not encompass pregnancy even if unwanted. Rather, those phrases suggested a need for harm or damage. The majority states that this approach was discussed with approval by Wild $\mathrm{J}$ in Teen $v$ ARCIC, ${ }^{29}$ and considers that the approach advanced by the Corporation also fits better with the consistent exclusion of various gradual processes under the different accident compensation regimes. ${ }^{30}$ They accept that the latter point is not determinative in that, as William Young P notes, a disease is a "natural" event yet can qualify as a physical injury. However, the majority relies on an explanation given by Stephen Todd in his article "The Court of Appeal, Accident Compensation and Tort Litigation": "[t]he difference is that pregnancy, unlike disease, is not pathological". ${ }^{31}$

In respect of overseas cases from Australia and England which demonstrate that "pregnancy" can be described as an injury, the majority state that these cases do not illustrate a uniform approach. ${ }^{32}$ Whilst acknowledging that common law developments may be of relevance to a case like this which is on the borderline, they go no further into an examination of these developments. ${ }^{33}$

27 Accident Compensation Corporation (submissions for the appellant in ACC v D [2008] NZCA 576, 10 July 2008) CA 329/07 at [3.2], [3.3] and [8].

28 D, above $\mathrm{n}$ 9, at [78] per William Young $\mathrm{P}$ dissenting.

29 Ibid, at [55] per Ellen France J, citing Teen $v$ Accident Rehabilitation and Compensation Insurance Corporation HC Wellington CIV-2003-485-1478, 22 September 2003 at [35] - [37] per Wild J.

30 Ibid, at [55].

31 Stephen Todd "The Court of Appeal, Accident Compensation and Tort Litigation" in Rick Bigwood (ed) The Permanent New Zealand Court of Appeal: Essays on the First 50 Years (Hart Publishing, Oxford, 2009) 152 at 178.

$32 D$, above n 9 , at [68].

33 Ibid. 
Further, the majority consider that the 1992 legislation was intended to narrow cover and reduce the "elasticity" of the previous regime. ${ }^{34}$ They consider that an "unniggardly" interpretation was a task which was only relevant prior to the 1992 amendments.

It is suggested that the majority took an ungenerous, restrictive interpretation to the policy behind accident compensation in New Zealand. A more inclusive approach, similar to the approach taken by Mallon $\mathrm{J}$, is argued to be more in line with the aims of the accident compensation scheme as it was first conceived.

\section{THE COURTS AND COVER FOR UNWANTED PREGNANCIES}

The advent of accident compensation in New Zealand consequently led to attempts to bring the common law "wrongful birth" cases within the cover provisions of the scheme, either as a "personal injury by accident" or through the concept of medical misadventure. ${ }^{35}$ The courts struggled with identifying a personal injury in conception, pregnancy or childbirth. ${ }^{36}$ An examination of how the courts have dealt with this issue in relation to the accident compensation legislation over the years reveals differing judicial interpretations to the policy behind the accident compensation scheme. The inclusive approach taken by Mallon $\mathrm{J}$ appears to mirror the attitude of the courts towards cover for unwanted pregnancies following failed sterilisations in the period from 1972 to 1992 and since 2003. The rather parsimonious approach of the majority in the Court of Appeal, however, appears to mirror the attitude of the courts in relation to such cases immediately following the legislative changes in 1992.

\section{A Reluctant Cover from 1972-1992}

The decisions in the period from 1972 to 1992 show, with some reluctance from the courts, that "wrongful birth" cases could be covered by the accident compensation scheme. ${ }^{37}$ The cases were described as instances of medical misadventure or of "personal injury by accident": "[t]he former phrase was easier as it avoided the difficulty of identifying the necessary personal injury under the latter phrase". ${ }^{38}$ The compensation which the mother was entitled to was limited to her physical and mental distress arising out of the pregnancy, and any loss of earnings during the pregnancy and birth. ${ }^{39}$ The courts did not see compensation extending to include the costs of child-rearing. ${ }^{40}$

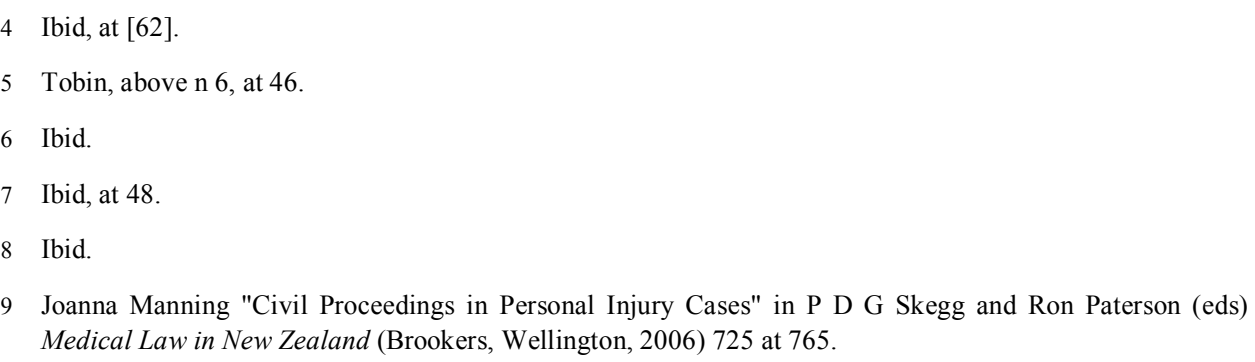


From 1972 to 1992 there was no real comprehensive statutory definition of personal injury. Under the Accident Compensation Act 1972 (the 1972 Act) cover was provided for "personal injury by accident" 41 and no other more comprehensive definition was provided. Under the Accident Compensation Amendment Act 1974 (the 1974 Act) and Accident Compensation Act 1982 (the 1982 Act), actual bodily harm (including pregnancy) from certain sexual offences was deemed to be "personal injury by accident". ${ }^{42}$ The 1974 Act also defined "personal injury by accident" as including "medical, surgical, dental or first aid misadventure". 43

The position of the courts in this early period appeared to have been influenced greatly by Cooke J's dicta in $L v M,{ }^{44}$ a case involving a failed sterilisation procedure performed on a woman, when the original 1972 definition of "personal injury by accident" applied. Cooke J said that because the 1972 Act had no relevant special definition, "personal injury by accident" had to be understood in its ordinary sense: ${ }^{45}$

In the ordinary sense the conception and the consequent childbirth can be said to have been caused by accident - namely the failure of the operation. But I do not think that either the conception or the childbirth could be described as a personal injury to the mother.

His Honour went on to say that he considered "physical and mental distress" to be a personal injury, caused by a mistake in the operation. ${ }^{46} \mathrm{He}$ also suggested that the expanded definition of "personal injury by accident" under the 1974 amendment meant that this might be a medical misadventure, and that it might not be necessary to also show what would ordinarily be called a personal injury. ${ }^{47} \mathrm{He}$ left this point to be decided in a future case, and subsequent cases took this position, so the courts did not need to decide whether pregnancy was a "personal injury" in its ordinary meaning. Provided that medical misadventure (through medical error or mishap) could be

40 Tobin, above $\mathrm{n} 6$, at 48 .

41 Accident Compensation Act 1972, s 2(1).

42 Accident Compensation Amendment Act 1974, s 2(1)(d). This section stated that "actual bodily harm" arising in specified instances fell under the definition of "personal injury by accident". These instances were defined in s 105B as including pregnancy arising from certain sexual offences; Accident Compensation Act 1982, s 2 .

43 Accident Compensation Amendment Act 1974, s 2.

$44 L v M[1979] 2$ NZLR 519 (CA).

45 Ibid, at 529 per Cooke J dissenting.

46 Ibid, at 530 per Cooke J dissenting.

47 Ibid 
shown, unwanted pregnancy and childbirth resulting from a failed sterilisation of the mother were treated as covered. ${ }^{48}$

$X Y \vee A C C^{49}$ was the sequel to $L v M$ and involved the same woman as in $L v M$. In between these two cases, the Corporation, presumably influenced by Cooke J's dicta, had granted her claim for cover on the basis that the conception of the child was caused by medical misadventure. This case concerned the extra expenses incurred in the maintenance of the child. The High Court declined this further claim, stating that what had been accepted as the "injury" (the pregnancy and birth) had healed after the birth of the child. ${ }^{50}$ In its judgment, the High Court was uncomfortable with viewing pregnancy and childbirth as an injury and whilst Jeffries $\mathrm{J}$ accepted the Corporation's decision to grant cover, he described it as "highly artificial". ${ }^{51} \mathrm{He}$ was unprepared to "stigmatise possibly the highest expression of love between human beings, that of a mother for her child, as a continuing injury to her by making compensation payable during dependency". 52

There was similar reluctance to view pregnancy and childbirth as an injury in ACC v Auckland Hospital Board. ${ }^{53}$ In that case, a woman had become pregnant following a failed tubal ligation procedure. The Corporation had initially refused cover, although this was reversed on appeal by the Accident Compensation Appeal Authority. In the High Court, Speight J upheld this decision: "[m]any persons might express surprise that the God-given ability to conceive and bear a child is to be described as a medical misadventure to be 'compensated'. But that in my judgment is the result to which I am driven by the legislation". ${ }^{54}$ The High Court did not discuss whether pregnancy was an "injury", because, consistent with the obiter view of Cooke $\mathrm{J}$ in $L v M$, the issue was whether what had occurred was a "medical misadventure" under the 1974 Act. If it was, it would be covered as a "personal injury by accident".

Tobin notes that she has no doubt that the "generous unniggardly" approach of the courts assisted in finding that "wrongful birth" cases could be covered by the 1972 and 1982 Acts. ${ }^{55}$ She suggests that these cases were on the path towards the comprehensive scheme that was envisaged by the Woodhouse Report, and reflected the objectives set out therein. ${ }^{56}$ However, the courts seemed to

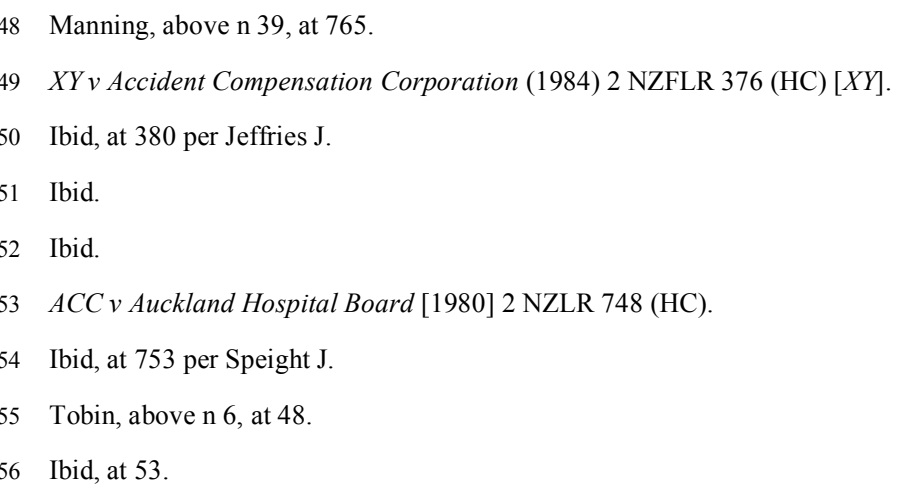


see this result as doing some violence to the definition of "injury" in the legislation. Whilst the courts appeared to accept the view that unwanted pregnancy and childbirth resulting from a failed sterilisation of the mother was treated as covered as a medical misadventure, the courts did not think it was an injury in the ordinary sense. ${ }^{57}$

\section{B Rejecting Cover Immediately Following the 1992 Act}

In the period immediately following 1992, unwanted pregnancies following failed sterilisations were denied cover. Many of the cases related to instances where there had been a failure to warn the woman about the potential risk of failure of the particular procedure chosen. ${ }^{58}$ The legislative changes to the definition of "personal injury" in 1992 appeared to be an "insurmountable hurdle"59 and thus the courts began to decline cover in failed sterilisation cases.

In 1992, the National Government turned its attention to limiting the accident compensation scheme and the Accident Rehabilitation and Compensation Insurance Act 1992 (the 1992 Act) was enacted. The National Government's motivation was in part its concern that an overly expansive conception of "personal injury by accident" had resulted in an "unsustainable increase in the number and cost of claims". ${ }^{60} \mathrm{~A}$ compartmentalised approach to personal injury sought to restrict the scheme's boundaries, introducing more precise definitions of the categories of covered personal injury, including the term "medical misadventure". ${ }^{61}$

This Act separated the cause (for example, "accident" and "medical misadventure") from the injury, so that proof of "personal injury" has been a pre-requisite for cover since 1992. There was no longer a non-exhaustive definition of "personal injury", nor express provisions concerning pregnancy caused by sexual offences. The 1992 Act defined "accident" to exclude anything that was treatment by, or at the direction of, a registered health professional. Thus once a registered health professional was involved in any given case, the qualifying category of cover would be medical misadventure. ${ }^{62}$ "Medical misadventure" was defined as personal injury that was caused either by "medical error" or "medical mishap". The former phrase was close in meaning to medical negligence, whilst the latter phrase occurred when a rare and severe "adverse consequence" resulted from properly received treatment. ${ }^{63}$

$57 A C C v D$, above n 10 , at [34].

58 Tobin, above $\mathrm{n} 6$, at 49 .

59 Ibid

60 Ken Oliphant "Beyond Misadventure: Compensation for Medical Injuries in New Zealand" (2007) 15 Med Law Review 357 at 359.

61 Ibid.

62 Accident Rehabilitation and Compensation Insurance Act 1992, s 8.

63 Ibid, s 5. 
The Accident Insurance Act 1998 (the 1998 Act) and the 2001 Act were similar to the 1992 Act. However, an amendment to the 2001 Act was made in 2005, due to a perception that the cover provisions for "medical misadventure" needed to be simplified. The concept of "treatment injury" replaced "medical misadventure", ${ }^{64}$ so that cover for personal injury "caused by treatment" became the new requirement. This amendment did not, however, alter the prerequisite for a personal injury. Claimants still need to have suffered a "personal injury" as a result of the actions or omissions of a registered health professional, which can be defined as "treatment injury".

Immediately following the enactment of the 1992 Act, District Court decisions took the view that conception and pregnancy were natural processes, not a "personal injury" to the mother. $D K v$ $A R C I C(D K)^{65}$ concerned a claim for emotional and mental anguish after a woman terminated her pregnancy which resulted from a failed sterilisation. The District Court held that pregnancy was not a physical injury under the 1992 definition. The termination was not seen as a physical injury either. The Court based its decision on a passage from Accident Compensation in New Zealand, where it was said that it is "well-established that pregnancy alone is not personal injury by accident". ${ }^{66}$

Subsequent District Court decisions upheld the position in DK. In $M M v A R C I C^{67}$ this was on the basis that pregnancy "by itself" was not an injury, and in Bell $v$ ARCIC $(B e l l)^{68}$ this was on the basis that there was no direct causal link between the pregnancy and the medical treatment. In Bell, the cause of the pregnancy was seen to be either intercourse or recanalisation of the fallopian tubes. Similarly, complications which arose immediately following childbirth were not seen as amounting to the necessary physical injury, as they were held to be spontaneous events which did not result from a health professional's actions. ${ }^{69}$ Further, in $M T v A R C I C,{ }^{70}$ a ruptured ectopic pregnancy was regarded as a naturally occurring physiological event which did not equate to physical harm or damage.

64 ACA, above n 11, s 20(2)(b). This was amended by section 13 of the Injury Prevention, Rehabilitation, and Compensation Amendment Act (No 2) 2005.

65 DK v Accident Rehabilitation and Compensation Insurance Corporation [1995] NZAR 529 (DC).

66 AP Blair (ed) Accident Compensation in New Zealand (2nd ed, Butterworths, Wellington, 1983) at [7.4].

67 MM v Accident Rehabilitation and Compensation Insurance Corporation DC Rotorua DN 79/96, DCA 217/95, 12 September 1996.

68 Bell v Accident Rehabilitation and Compensation Insurance Corporation DC Wellington DN 98/99, DCA 98/96, 22 April 1999.

69 Pritchard v Accident Rehabilitation and Compensation Insurance Corporation DC Wellington DN 104/96, DCA 267/95, 3 October 1996.

70 MT v Accident Rehabilitation and Compensation Insurance Corporation DC Rotorua DN 91/96 DCA 277/95, 25 September 1996. 
This more parsimonious approach to the policy behind accident compensation in relation to unwanted pregnancies has been described as inconsistent with the original Woodhouse principles. ${ }^{71}$ Cover for pregnancy in failed sterilisation cases was declined, as presumably some other physical injury from the pregnancy and childbirth or the sterilisation procedure was thought to be required. Tobin comments that this change in judicial attitude failed to acknowledge that the meaning of "personal injury by accident" in a case that also involved medical misadventure was an "integrated one, holistic, to be seen and applied as a whole and without breaking it down into its component parts". 72

\section{A Move Towards Cover?}

Tobin describes more recent decisions as suggesting a move that reflects what occurred in the early period, when courts were recognising unplanned pregnancy cases within the accident compensation scheme. She notes that "[t]he courts are getting more comfortable with the ACC legislation, and more willing to expand the definition of personal injury - although given the confines of the legislative definition this is rather difficult to justify". ${ }^{73}$

In 2003, an indication of a more generous approach was seen in Harrild $v$ Director of Proceedings (Harrild), ${ }^{74}$ where the Court of Appeal needed to consider whether the death of a developing foetus was a personal injury to the mother. The majority held that a "generous unniggardly" approach to the interpretation of the phrase "personal injury" was appropriate, thus allowing cover in the case of death to a foetus in utero. ${ }^{75}$ Tobin notes that the Court of Appeal had again begun to use words which were "more applicable to the 1972 and 1982 Acts" and that this was "no doubt due to the reference to the social contract entered into when New Zealanders gave up the right to sue for personal injury, and which is now embedded in the 2001 Act". ${ }^{76}$ In Harrild, Elias CJ stated: ${ }^{77}$

The policy of the legislation is to provide comprehensive cover to compensate for personal injury...in replacement of the remedies previously available under the common law. I agree with Keith $\mathbf{J}$ and McGrath $\mathrm{J}$ that the legislative policy is not to be undermined by an ungenerous or niggardly approach to the scope of the cover provided.

71 Tobin, above n 6, at 53 .

72 Ibid, at 40.

73 Ibid, at 52.

74 Harrild v Director of Proceedings [2003] 3 NZLR 289 (CA) [Harrild].

75 Ibid, at [19] per Elias CJ; at [39] per Keith J; at [80] and [130] per McGrath J. The reference to a "generous unniggardly" approach was first seen in ACC v Mitchell [1992] 2 NZLR 436 (CA) at 438 per Richardson J.

76 Tobin, above $\mathrm{n} 6$, at 52 .

77 Harrild, above n 74, at [19] per Elias CJ. 
In relation to failed sterilisations, two High Court decisions, $S G B v W D H B(S G B)^{78}$ and Patient $A v$ Health Board $X$ (Patient A), ${ }^{79}$ have disagreed with the restrictive view of the District Courts following the enactment of the 1992 Act. In $S G B$, a sterilisation procedure was performed on a man, not a woman. The man and his wife alleged that the surgeon failed to warn them of the risk that the effects of the vasectomy might be reversed by the natural processes of the body. The Court needed to consider whether the proceedings were barred by the provisions of the accident compensation legislation. The case was considered under the 1998 Act, but "the decision is equally applicable to the 2001 Act". ${ }^{80}$ The Court held that the wife had not suffered a personal injury caused by medical misadventure, as she was not the patient. Thus the Court did not need to decide whether pregnancy was a personal injury. However, the Court noted (obiter) ${ }^{81}$

It perhaps could be argued that if there is an abnormal reaction to treatment given to a woman in circumstances where medical error or mishap occurs "at the time of the treatment" then conception might be "personal injury". For example a medical error or mishap at the time of surgical performance of a tubal ligation so that a woman later suffers a "complication" of conception might fall within the definition of personal injury in s 35(2). That, however, is quite a different situation to where a woman conceives naturally and gives birth in the situation where the accidental conception did not arise out of any medical error because of treatment given to her.

Patient $A$ involved a mother becoming pregnant after a failed tubal ligation, and her claim for damages was based on a negligent failure to warn her that the sterilisation operation might not be successful. Baragwanath J's discussion of the law in that case has been described as unhelpful because his Honour appears to have confused pre-1992 law and post-1992 law. ${ }^{82}$ Baragwanath J first asked whether the wife had suffered a "personal injury by accident". It was only after deciding that she had suffered a "personal injury" but not an "accident" that his Honour considered medical misadventure. In his view, there could be cover on that basis. However, under the 1992 regime that was being discussed, "personal injury by accident" and "medical misadventure" were mutually exclusive. ${ }^{83}$ "Accident" under the Act excluded anything that was treatment by a registered health professional, so the only qualifying category of cover was medical misadventure.

Nevertheless, Baragwanath J's discussion of "personal injury" is interesting, as his Honour saw the failure of the Filshie clip attached to her fallopian tube as an injury to the woman and

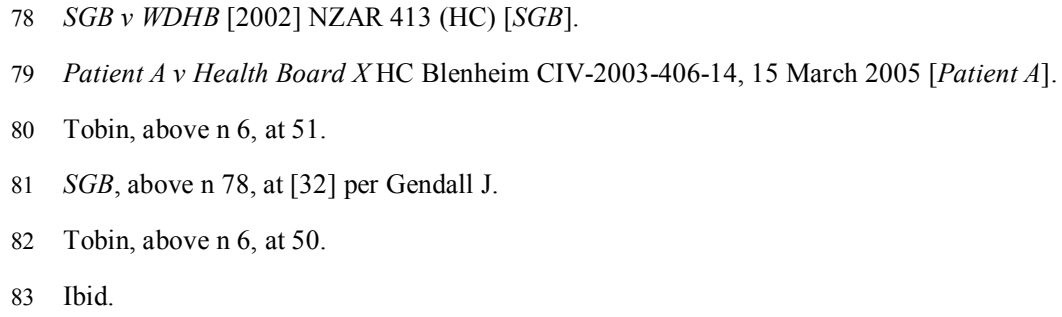


constituting an interference with her bodily integrity. ${ }^{84}$ The consequence of its failure was that she became pregnant. His Honour said that "injury" is viewed from the victim's perspective, and that to her, the prospect of pregnancy was not a joy but a burden. Accordingly, the failure of the clip and resulting pregnancy could be regarded as a "personal injury". 85

The foregoing analysis illustrates two different judicial interpretations being taken towards the accident compensation scheme in relation to unwanted pregnancy following a failed sterilisation. The inclusive approach, seen from 1972 to 1992, and more recently since 2003, is an appropriate description of Mallon J's decision in the High Court. Conversely, the decision of the majority in the Court of Appeal in ACC v D reflects a more restrictive approach, as seen by the courts immediately following the legislative amendments in 1992. This is arguably out of step with the more recent developments since 2003. The divergence in approach suggests an underlying difference in the courts' perception of the policy behind the accident compensation scheme. It is therefore necessary to consider the appropriate approach to statutory interpretation of the 2001 Act.

\section{INTERPRETING THE ACCIDENT COMPENSATION SCHEME}

Three propositions are put forward. Firstly, there is a real difficulty in drawing a workable distinction between natural processes which are intended to be covered by the scheme and those which are not. This suggests that the issue of statutory interpretation must be resolved through a broader inquiry of the context, purpose and policy of the Act. Secondly, the natural and ordinary meaning of the words "physical injuries" in the 2001 Act should be examined in light of common law developments in other jurisdictions. These developments suggest that pregnancy can be considered as an "injury". Finally, the purpose and policy of the 2001 Act suggests that an inclusive approach to accident compensation cases, particularly those on the borderline, should be taken by the courts. Thus in such cases, the courts should err on the side of caution, and grant cover. If this is not seen to be an appropriate outcome by Parliament, legislative amendments could be made where necessary.

This suggested approach accords with the courts taking an "unniggardly" approach. Judges "should perhaps interpret the statutory words used as widely as possible to bring about [the vision of the Woodhouse Report]". 86 The concept of "injury" would not be static and unchanging, but rather it would be both "appropriate and inevitable that judges will draw upon the concept of injury or accident developed not just in New Zealand but also by common law courts in other jurisdictions". ${ }^{87}$

84 The phrase "interference with her bodily integrity" comes from Green v Matheson [1989] 3 NZLR 564 (CA) at 572 per Cooke P.

85 Patient $A$, above $\mathrm{n} 79$, at [55] per Baragwanath J.

86 Geoff McLay "Accident Compensation - What's the Common Law Got to Do With It?" [2008] NZ Law Review 55 at 72.

87 Ibid. 
Richard Gaskins reads the Woodhouse Report as paving the way forward in a manner that "includes making the right incremental changes to the ACC scheme as we know it today". ${ }^{88} \mathrm{He}$ says it also "calls for the same kind of creativity and clarity that we find in this remarkable report. Today the failure to think comprehensively may have serious costs of its own". ${ }^{89}$

It is not argued that the accident compensation scheme should cover the costs of raising a child who is born following a failed sterilisation. Rather, there should be compensation for the mother's physical and mental distress, medical expenses, and loss of earnings during the pregnancy, birth, and immediately afterward. In both New Zealand and in other jurisdictions, expenses for raising a child have generally been considered as "too remote" from the medical misadventure. ${ }^{90}$ This recognises that the line must be drawn somewhere, and that there are strong policy reasons against burdening levy-payers, rather than parents, with the potentially large costs of raising a child. ${ }^{91}$

\section{A Natural and Ordinary Meanings}

\section{The problem of natural processes}

The issue of statutory interpretation in $A C C v D$ was whether pregnancy is a "personal injury" under the accident compensation legislation. The reasoning of both the High Court and the Court of Appeal thus focuses on the natural and ordinary meanings of "personal injury" and "physical injuries".

The phrasing of the issue in this way follows from the manner in which D first claimed under the medical misadventure provisions of the Act, through the standard application form lodged by her medical practitioner. The physical injury for which she claimed was "pregnancy". The date of the injury was presumably the date of the conception, and the claim was lodged prior to the child's birth. Some confusion over the identification of the complained injury is seen by the Corporation wrongly asserting that it was the birth of the child which was the injury about which D complained. ${ }^{92}$ This confusion mirrors the difficulty seen in common law "wrongful birth" cases in identifying the cause of the harm suffered by a complainant - whether it is the conception, pregnancy or childbirth.

Quite apart from identifying the relevant injury, however, was the significant issue of the relationship of natural processes with the accident compensation scheme. Both the High Court and the Court of Appeal were faced with the difficult task of determining whether pregnancy (a natural

88

89

90

9

92

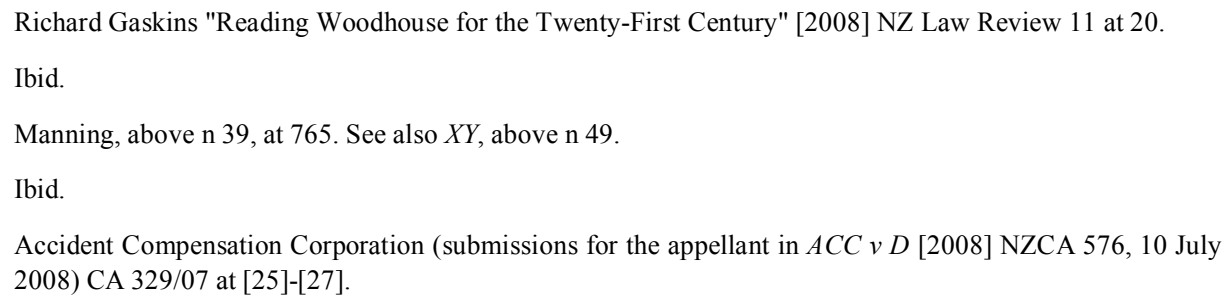


process) could fit under the umbrella of the accident compensation scheme, in view of the consideration that a major, general exclusion from the scheme has been cover for gradual processes. ${ }^{93}$ It is not hard to agree that the physical consequences of pregnancy which are described by Mallon J are a "physical injury" within the natural and ordinary meaning of that term. However, one could say the same about a number of medical conditions. One still needs to ask whether the term "physical injuries" under the Act was intended to capture natural processes, given the general exclusion of gradual processes under the differing accident compensation regimes.

This suggests that the true issue for determination was not whether "pregnancy" is a "personal injury", but rather whether there could be cover for the consequences of a failed sterilisation. To ask whether the failure of the sterilisation operation is a "personal injury" would be similar to asking whether a failure to diagnose growing malignant cells is a "personal injury". The injury in the latter scenario would not be the cancer, but the failure to diagnose. It is clear that cover is available, as this is a "paradigm case of medical misadventure", notes William Young P. 94 Thus in $A C C v D$, if the consequences of failing to provide an effective sterilisation were not covered, this would throw the position of cover for the consequences following other failed procedures under considerable doubt and "put at risk the nature of cover provided for 'medical misadventure', or now 'treatment injury"'. ${ }^{95}$

The result of obscuring this important issue is that the Court of Appeal gives a rather unsatisfactory answer to the question of whether this type of natural process is intended to be covered by the Act. The majority attempts to deal with the problem by suggesting that a personal injury caused by medical misadventure which is a natural process needs to be "pathological". 96 No definition of this term is given. However, the majority cites Todd's 2009 article "The Court of Appeal, Accident Compensation and Tort Litigation". The relevant passage of the article notes that pregnancy can not be treated as a physical injury because it is a physiological rather than pathological event; however, no further explanation of this distinction's rationale or example of its application is given: ${ }^{97}$

The core objections to treating pregnancy as physical injury are that: (i) pregnancy is a natural physiological event; and (ii) whether such injury has been suffered in any particular case may depend on whether the mother does or does not want to become pregnant. However, as regards the first objection, a disease is a "natural" event, yet it certainly can qualify as physical damage. The difference is that pregnancy, unlike disease, is not pathological....

93 ACA, above n 11, s 26.

$94 D$, above $\mathrm{n}$ 9, at [77] per William Young $\mathrm{P}$ dissenting.

95 McLay, above $\mathrm{n} 86$, at 74.

$96 D$, above n 9, at [55].

97 Todd, above n 31, at 180. 
The majority's differentiation between pathological and physiological natural processes is an attempt to draw the line between natural processes which are covered by the Act, and those which are not. However, the difficulty in applying this distinction is in determining what exactly is "pathological". Presumably "pathological" means "involving, caused by, or of the nature of a disease".$^{98}$ It is unclear whether the majority is suggesting that the root of the injuries suffered must be pathological, or whether it is sufficient that some or all of the consequences of the injury are pathological.

For example, there could be a situation where a natural process is apparent, when the body responds in a detrimental but natural way to an "accident", or to medical treatment given or omitted. The paradigm case of a misdiagnosis of cancer has already been mentioned. The health professional who failed to make the correct diagnosis did not cause a "pathological" condition or injury, but cover is granted because that condition or injury was allowed to follow a natural course and worsen unchecked. The majority's failure to address the position of cover for these types of consequences puts the position of this "paradigm" case and other failed procedures under considerable risk. These problematic issues relating to natural processes suggest that the issue of statutory interpretation must be resolved through a broader inquiry of the context, purpose and policy of the Act.

\section{Changing common law perspectives}

Common law actions for "wrongful birth" have appeared in Australia and England, concerning either the birth of a healthy or disabled child, from healthy or disabled parents. The courts have been faced with the difficult question of whether the law should allow recovery of damages in the case of the birth of an unplanned child resulting from negligent medical treatment or advice. In the High Court, Mallon J considered that the developments in other jurisdictions in this area of the common law illustrate that pregnancy can be described as an "injury", either because it is a "harm", or an invasion of bodily integrity despite being a natural bodily process. ${ }^{99}$ As the following cases demonstrate, the moral and social perception of the birth of a child as a "blessing" has given way considerably to the parents' right to determine the size of their family.

In Cattanach v Melchior, ${ }^{100}$ before the High Court of Australia, a husband and wife made a claim in negligence, on the basis that there had been a failure to warn of the potential failure of the sterilisation procedure performed on the wife. The High Court allowed a claim for damages for pain and suffering and loss of the amenities of life associated with pregnancy and childbirth, and the financial consequences of the pregnancy and childbirth (medical expenses and lost earnings). Kirby $\mathrm{J}$ commented that social attitudes to various forms of contraception, including sterilisation, had

Concise Oxford English Dictionary (11th ed, Oxford University Press, 2004) at 1049.

$99 A C C v D$, above n 10 , at [65].

100 Cattanach v Melchior (2003) 199 ALR 131 (HC). 
changed in Australia since the 1960s. ${ }^{101}$ He perceived the impact to the mother to be a "direct injury" 102 involving her person, a "physical injury suffered by the mother" 103 and involving a "physical and emotional impact on the mother". ${ }^{104}$ Hayne J referred to interference of "the physical integrity of an individual's person". 105

In England, the House of Lords in McFarlane $v$ Tayside Health Board ${ }^{106}$ allowed a claim for the pain and distress suffered by a woman during her pregnancy and in giving birth, and for financial loss associated with the pregnancy. The House of Lords recognised that to cause a woman to become pregnant and bear a child against her will was an invasion of that fundamental right to bodily integrity. ${ }^{107}$ Lord Hope of Craighead and Lord Slynn of Hadley referred to a loss of autonomy rather than harm, and concerning whether there should be compensation for what is a natural process, Lord Steyn said: ${ }^{108}$

Counsel for the health authority argued as his primary submission that the whole claim should fail because the natural processes of conception and childbirth cannot in law amount to personal injury. This is a view taken in some jurisdictions. On the other hand, it is inconsistent with many other decisions, notably where limited recovery of compensation for pain, suffering and distress is allowed. I would not follow this path.

The English Court of Appeal, in Parkinson v St James, ${ }^{109}$ allowed a claim for damages for the additional costs of raising a disabled child conceived after a negligently performed sterilisation operation. Hale LJ discussed the issue of the interest affected by an unwanted pregnancy, saying that conception, pregnancy and childbirth could be considered an invasion of bodily integrity. ${ }^{110}$ Similarly in Rees $v$ Darlington, ${ }^{111}$ the House of Lords considered the recoverability of damages in failed sterilisation cases. There, the claimant was a handicapped woman who underwent a sterilisation operation which was negligently performed. Subsequently she became pregnant and

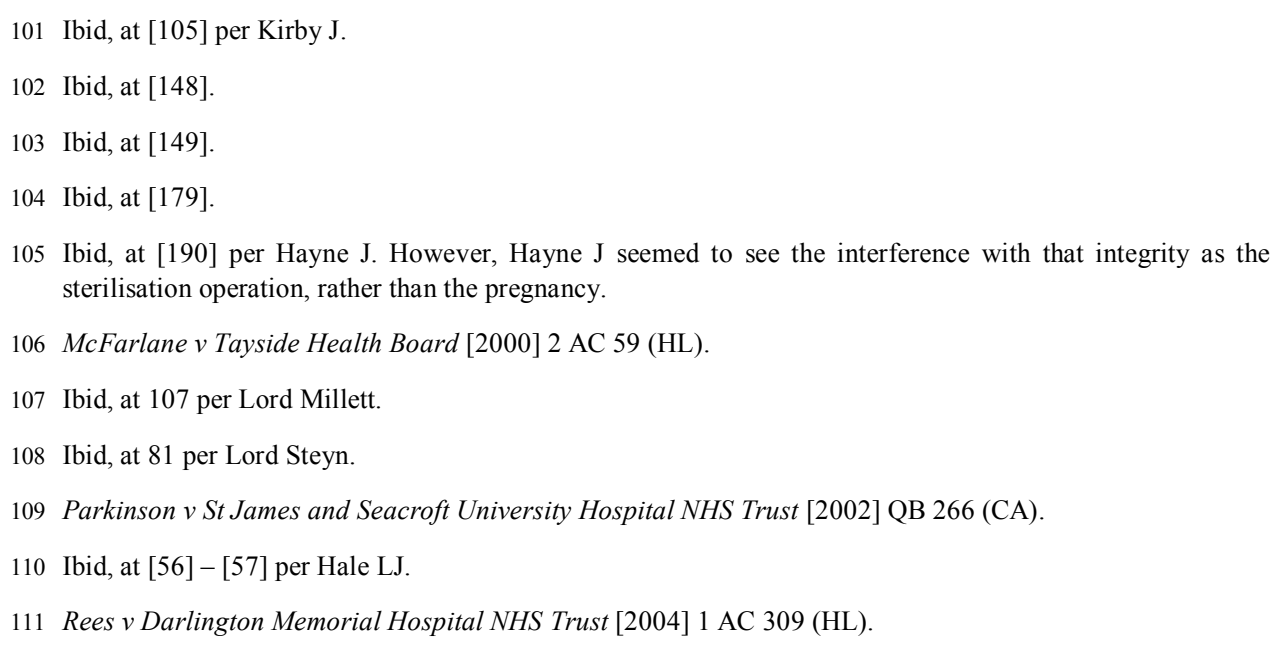


gave birth to a healthy baby. It was implicit in some of the judgments that damages would be available for pregnancy, although not for the costs of raising the child. ${ }^{112}$

The common law "continues to play an important part in the interpretation and understanding of the accident compensation scheme". ${ }^{113}$ Geoff McLay describes the relationship between the accident compensation scheme and the common law as "a generator of ideas about how to compensate accidents and the sort of injuries that ought to be recognised". ${ }^{114}$ The majority in the Court of Appeal do not see the common law developments as particularly illuminating. However, this fails to recognise that the relevance of common law developments for the interpretation of the accident compensation scheme follows from the "trade-off" reflected by the scheme.

The English and Australian cases of unwanted pregnancy illustrate that the New Zealand cases are out of step with the common law developments in failed sterilisation cases, which have recognised the changed social context in which we now live. Where pregnancy has resulted from negligent sterilisation procedures, damages have been awarded for the direct consequences of the pregnancy and childbirth: pain and suffering, medical expenses and loss of income. Mallon J's judgment has been described as an example of the New Zealand courts "learning from overseas common law developments" where there was "clearly some place for growth in the way that the...Act might be interpreted". ${ }^{115}$ McLay writes: ${ }^{116}$

[T] he need to change or grow at the margins is a key lesson from the tort law system that the ACC system needs to learn. New Zealand has the great advantage of being able to learn from common law developments in other jurisdictions - they serve an important function in providing a frame of reference by which New Zealand judges assess what the ACC scheme ought to be covering.

\section{B Purpose and Policy}

The difficulty in resolving the issue relating to natural processes and whether they are to be regarded as "physical injuries" suggests that the issue in $A C C v D$ can not be resolved purely by an interpretation of the natural and ordinary meaning of "physical injuries". An examination of the purpose and policy behind accident compensation legislation is a legitimate part of statutory interpretation, as the meaning of an enactment must be ascertained from its text and in light of its

112 Ibid, at [123] per Lord Millett.

113 McLay, above n 86, at 61.

114 Ibid.

115 Ibid, at 71 .

$116 \mathrm{Ibid}$, at 62 . 
purpose. ${ }^{117}$ In order to illustrate support for an inclusive interpretation of the accident compensation scheme, the principles of the scheme are traversed.

\section{Comprehensive entitlement and the removal of the right to sue}

The corollary of comprehensive cover under the accident compensation scheme in New Zealand was the removal of the right to sue at common law for personal injury. ${ }^{118}$ The vision for accident compensation in New Zealand came from the Royal Commission on Compensation for Personal Injury in New Zealand, which reported in 1967 and was chaired by Sir Owen Woodhouse. ${ }^{119}$ In relation to comprehensive entitlement, the Woodhouse Report ${ }^{120}$ stated that "all injured persons should receive compensation from any community financed scheme on the same uniform method of assessment, regardless of the causes which gave rise to their injuries", 121 "any discrimination between people in the same general situation could hardly be justified", ${ }^{122}$ and that: ${ }^{123}$

It cannot be regarded as just that workmen sustaining equal losses should be treated unequally by society ... there can be no justification for providing from community funds for the same class of worker entirely inconsistent awards for precisely similar incapacities merely because fortuitously the causes which gave rise to them have at different stages of our social development been the subject of conflicting responses.

In the High Court, Mallon $\mathrm{J}$ acknowledged that the policy of the scheme was to provide comprehensive cover, and that New Zealanders had given up their right to sue in exchange for that comprehensive cover. ${ }^{124}$ She stated that as a matter of policy, it is difficult to see the justification for requiring patients to bring common law claims. Similarly, it is hard to justify exposing medical professionals to common law claims when the policy of the accident compensation regime is to exclude such claims. These considerations are in line with section 3 of the 2001 Act, which states the purpose of the legislation as including the reinforcement of the "social contract" represented by the first accident compensation scheme.

117 Interpretation Act 1999, s 5(1).

118 Bill Atkin, Geoff McLay and William Hodge (eds) Torts in New Zealand: Cases and Materials (4th ed, Oxford University Press, 2006) at 120.

119 Ibid, at 119.

120 Woodhouse Report, above $\mathrm{n} 1$.

121 Ibid, Part II, at [55].

122 Ibid, Part II, at [43].

123 Ibid, Part II, at [57].

$124 A C C v D$, above n 10, at [91]. 
In Bridgeman $v A C C,{ }^{125}$ Thorp $\mathrm{J}$ recognised the importance of this social contract and the desirability of achieving consistency between those individuals whose claims have been determined and those whose claims remain for determination. The physical consequences of an unwanted pregnancy following a failed sterilisation procedure are the only physical consequences of medical misadventure for which the Corporation has not provided cover, except where Parliament has expressly legislated to the contrary. ${ }^{126}$ To refuse cover would therefore create an arbitrary distinction between this case and other cases where unintended physical injuries or outcomes result from surgery. It would also create an anomaly for the medical practitioners who perform sterilisations, and the patients who undergo the procedures. These are strong policy reasons which support cover and it is suggested that the majority did not pay sufficient regard to this point. A generous approach to the types of injuries covered is appropriate and consistent with the founding purpose of the scheme to provide cover instead of leaving compensation to be determined by personal injury litigation.

\section{The demise of a "generous unniggardly" approach?}

The reference to avoiding an ungenerous or niggardly approach came from Richardson $\mathrm{J}$ in $A C C$ v Mitchell: ${ }^{127}$

... a generous unniggardly interpretation of personal injury by accident is in keeping with the policy underlying the Accident Compensation Act of providing comprehensive cover for all those suffering personal injury by accident in New Zealand wherever, whenever and however occurring, and to do so in place of common law remedies. Certainly if the expression is fairly capable of covering all accidental injuries whether or not precipitated by an external triggering incident, that interpretation would better reflect the philosophy underlying this major social legislation.

Before the Court of Appeal, the Corporation submitted that the "generous unniggardly" approach was developed in ACC v Mitchell under the 1982 legislation, and when considering it in this particular context, regard has to be given to the fact that, undeniably, more restricted definitions of personal injury were introduced in $1992 .{ }^{128}$ The majority accepted that a "generous unniggardly" approach was no longer a task relevant to the courts following the 1992 Act, placing emphasis on the point that "it is plain that the 1992 legislation was intended to narrow cover and reduce the 'elasticity' of the previous regime". ${ }^{129}$ This view is also held by critics of "unreflective judicial

125 Bridgeman v Accident Compensation Corporation [1993] NZAR 199 (HC).

126 Madhuri Ballal (submissions for the Second Respondent in ACC v D [2008] NZCA 576, 26 June 2008) CA $329 / 07$ at [8] and [50].

127 ACC v Mitchell [1992] 2 NZLR 436 (CA) at 438-9 per Richardson J.

128 Accident Compensation Corporation (submissions for the Appellant in ACC v D [2008] NZCA 576, 10 July 2008) CA 329/07 at [29.2].

$129 D$, above n 9 , at [62]. 
expansionism", who do not see it in the courts' power to adjust levy rates and risk upsetting the principle of fiscal responsibility. ${ }^{130}$

It is true that since 1992, "the scope for expansive judicial interpretation of covered personal injury has been limited by the more detailed statutory formula"131 introduced by the 1992 Act. The 1992 Act restricted the scope of cover in certain areas, for example through introducing a strict three-stage test for work-related gradual process disease and infection, requiring mental injury to arise out of a physical injury, and re-defining "medical misadventure". ${ }^{132}$ However, while the Act was undoubtedly limiting the ambit of recovery in specific areas, it did not intend to subvert a key Woodhouse principle, namely comprehensive entitlement. The National Government Ministers expressly confirmed the remaining validity of the Woodhouse principles. ${ }^{133}$ Some commentators have argued that the legislative controls in 1992 were imposed in reaction to the "generous unniggardly" approach seen in cases such as ACC v Mitchell, but that these measures "lacked any coherent principle and were motivated solely by a desire to constrain the costs of the scheme. The absence of any legislative guidance on policy might suggest that continuing reliance on a Woodhouse vision can still be supported". 134

Further, in 2003, the Court of Appeal majority in Harrild cited the principle of taking a "generous unniggardly" approach with approval. ${ }^{135}$ Todd notes: ${ }^{136}$

Interestingly, the majority saw the approach to interpreting the legislation as being unaffected by the 1992 changes... Keith J recognised that since Mitchell the coverage of the legislation has been more precisely defined and in some respects narrowed, but he did not see those changes as affecting the instant case.

In relation to the replacement of the concept of "medical misadventure" by "treatment injury" in 2005, Ken Oliphant notes that "[t]here has been a decisive shift from a regime (medical

130 Ken Oliphant "Beyond Woodhouse: Devising New Principles for Determining ACC Boundary Issues" (2004) 35 VUWLR 915 at 922-6. This is referred to in Todd, above n 31, at 178.

131 Ibid, at 923.

132 John Miller "Trends in Personal Injury Litigation: the 1990s" (2003) 34 VUWLR 407 at 408-410.

133 Geoffrey Palmer "New Zealand's Accident Compensation Scheme: 20 Years On" (1994) 44 U Toronto LJ 223 at 226.

134 Todd, above n 31, at 178-9. Todd was paraphrasing the argument made by commentators such as Rodney Harrison and TG Ison in: Rodney Harrison (ed) Matters of Life and Death: The Accident Rehabilitation and Compensation Insurance Act 1992 and Common Law Claims for Personal Injury (Legal Research Foundation, Auckland, 1993); and TG Ison "Changes to the Accident Compensation System: An International Perspective" (1993) 23 VUWLR 25.

135 Harrild, above n 74, at [19] per Elias CJ; at [39] per Keith J; at [80] and [130] per McGrath J.

136 Todd, above n 31, at 177. 
misadventure) in which the majority of claims were rejected, to one (treatment injury) in which a majority of claims are now accepted". ${ }^{137}$ These observations suggest that the 1992 amendments, whilst intending to narrow the scope of cover in certain respects, were not intended to prevent recovery in relation to cases such as the one before the Court of Appeal. The overall "generous unniggardly" approach taken by the courts prior to 1992 was not to be defeated by virtue of specific, express clarifications made by Parliament about the limits of recovery in the 1992 amendments. The current view is that where a question as to the scope of the cover provided by the Act is in issue, "a 'generous unniggardly' approach to interpreting the statute ought to be taken". ${ }^{138}$

\section{CONCLUSION}

This article supports a more inclusive judicial interpretation of the policy behind accident compensation in New Zealand. It is argued that this would be more in line with the aims of accident compensation as it was first conceived by Woodhouse, particularly in borderline cases such as $A C C$ $v D$. Whilst it is accepted that the 1992 amendments were aimed at reducing the cost of the accident compensation scheme and the number of potential claimants, ${ }^{139}$ it is argued that the guiding principles of the earlier regime are not to be forgotten. The interplay between common law suits and coverage highlights the importance of determining an appropriate interpretative approach to the accident compensation scheme. The notion that New Zealanders have entered into a social contract by giving up the right to sue for personal injury is now embedded in the 2001 Act, ${ }^{140}$ and "[t]he social contract...must evolve in response to changed needs if the scheme is to retain its credibility and public support". ${ }^{141}$

137 Oliphant, above n 60, at 387.

138 Todd, above $\mathrm{n} 4$, at 32 .

139 Tobin, above $\mathrm{n} 6$, at 38 .

140 Ibid, at 52 .

141 Susan St John "Reassessing the Links with Health and the Welfare State" (2004) 35 VUWLR 779 at 779. 